\title{
CAKUPAN DAN DETERMINAN PEMBERIAN ASI EKSKLUSIF DI PEMUKIMAN KUMUH DALAM PERKOTAAN DI KECAMATAN TALLO KOTA MAKASSAR
}

\author{
Erwin La Aga*, La Ode Alifariki* ${ }^{* \uplus \square}$
}

\begin{abstract}
Abstrak
Secara global cakupan ASI eksklusif mencapai 36 persen pada tahun 2011. Menurut Riset Kesehatan Dasar 2013, cakupan ASI eksklusif mencapai 38\% di Indonesia, yang masih jauh dari target World Health Assembly (WHA) yaitu 50\% pada tahun 2025. Penelitian ini bertujuan menilai cakupan dan determinan pemberian ASI eksklusif. Rancangan penelitian adalah cross sectional. Wawancara dilakukan pada 221 wanita yang mempunyai bayi berusia antara 7-12 bulan. Studi ini dilakukan di tujuh pemukiman kumuh dari sembilan lokasi kumuh yang ditetapkan oleh pemerintah daerah Makassar. Analisis multivariat menggunakan perangkat lunak SPSS. Cakupan pemberian ASI eksklusif di pemukiman kumuh dalam perkotaan Kota Makassar adalah 20,4\%. Hasil uji multivariat menunjukkan hubungan bermakna sikap ibu (OR $=3,458$; $95 \% \mathrm{Cl}=1,626-7,354)(\mathrm{P}=0,001)$ dan kunjungan $\mathrm{ANC}(\mathrm{OR}=5,124 ; 95 \% \mathrm{Cl}=1,162-22,597)(\mathrm{P}=0,031)$ dengan pemberian ASI eksklusif. Namun, umur ibu, etnik, jenis persalinan, paritas, tempat persalinan, pekerjaan ibu, pendapatan keluarga, pendidikan ibu, pengetahuan, keterpaparan informasi, dukungan suami, dukungan keluarga, dukungan petugas kesehatan tidak berhubungan dengan pemberian ASI eksklusif. Faktor predisposisi yang berhubungan bermakna dengan pemberian ASI eksklusif pada bayi sampai usia sampai 6 bulan adalah sikap ibu. Sikap positif ibu tentang ASI eksklusif memiliki kemungkinan memberikan ASI eksklusif dibanding dengan ibu yang bersikap negatif. Maka, perlu upaya perbaikan pada sikap ibu tentang ASI eksklusif, komunikasi, informasi dan edukasi (KIE) tentang kolostrum, inisiasi menyusu dini (IMD), pemberian makanan prelakteat lebih ditingkatkan dengan cara konseling tentang ASI eksklusif sejak prapersalinan.

Kata kunci: asi eksklusif, Kota Makassar, pemukiman kumuh.
\end{abstract}

\section{COVERAGE AND DETERMINANTS OF EXCLUSIVE BREASTFEEDING IN URBAN SLUM AREA AT TALLO DISTRICT OF MAKASSAR CITY}

\begin{abstract}
Globally, coverage of exclusive breastfeeding reached $36 \%$ in 2011. According to fundamental health research (Riskesdas) 2013 the coverage of exclusive breastfeeding in Indonesia reaches $38 \%$, which is far from the World Health Assembly (WHA) target of 50\% in 2025. The aim of the research was to assess the coverage and determinant of exclusive breastfeeding. The research design was cross sectional. There were 221 women who have infant with range of age 7-12 months were interviewed. The study was conducted in seven slum areas from nine slum areas which are determined by the local government of Makassar. Multivariate analysis was done by SPSS application. The coverage of exclusive breastfeeding in the slum area is $20.4 \%$. Multivariate analysis indicates a significant correlation between mothers' attitude and exclusive breastfeeding $(\mathrm{OR}=3.458 ; 95 \% \mathrm{Cl}=1.626-7.354)(\mathrm{P}=0.001)$ and antenatal care $(\mathrm{OR}=5.124$; $95 \% \mathrm{Cl}=1.162-22.597)(P=0.031)$. However, there were no correlation between age, ethnic, birth types, parity, birth place, occupation, family income, mother's education, knowledge, exposure of information, husband support, family support and health officials with exclusive breastfeeding. Predisposing factor related to exclusive breastfeeding to infants up to six months are the mother's attitude. Mothers with positive attitude in breastfeeding will give exclusive breastfeeding than negative mothers. Therefore, it is necessary to improve the mother's attitude about exclusive breastfeeding, communication, information and education about colostrum, and prelacteat feeding are further enhanced by counseling about exclusive breastfeeding before delivery.

Keywords: exclusive breastfeeding, Makassar City, urban slum area.
\end{abstract}

*Dinas Kesehatan Pemda Kabupaten Buton Utara, Sulawesi Tenggara

"Konsentrasi Keperawatan, Fakultas Kedokteran, Universitas Halu Oleo

E-mail: ners_riki@yahoo.co.id 


\section{Pendahuluan}

Pemberian ASI pada bayi tanpa makanan atau cairan apapun kecuali obatobatan atau vitamin dan mineral disebut ASI eksklusif. ${ }^{1}$ Secara keseluruhan, pemberian ASI eksklusif dapat mempengaruhi keberlanjutan hidup dan perkembangan anak. $^{2}$ ASI mengurangi morbiditas dan mortalitas dengan mengurangi penyakit menular. Selain itu, menyusui dapat meningkatkan perkembangan kognitif anak dan melindungi anak dari risiko penyakit. ASI eksklusif dapat meningkatkan status gizi secara langsung atau dapat mengurangi infeksi. ${ }^{3}$

ASI adalah sumber utama nutrisi yang memiliki komposisi bioaktif dan secara ilmiah dapat menjaga kehidupan bayi dan anak-anak, dan meningkatkan status kesehatan ibu dan anak. ${ }^{4}$ ASI eksklusif penting mencegah stunting dan kegemukan pada anak-anak. ${ }^{3}$ Menyusui mengurangi risiko diare empat hingga enam kali lipat dan risiko penyakit pernapasan lima kali lipat.5,7 Bayi yang mendapatkan ASI Eksklusif merupakan salah satu indikator utama status kesehatan sebuah keluarga.$^{19}$

ASI menjadi dasar ilmiah utama yang harus disediakan pada awal jam pertama untuk bayi yang lahir lemah. ASI memberikan banyak manfaat untuk imunologi, psikologis, sosial, ekonomi, dan lingkungan. Hasilnya berupa peningkatan kesehatan ibu dan bayi, baik di negara-negara berpenghasilan menengah bawah dan negara-negara penghasilan tinggi. ${ }^{6}$

Hasil survey kesehatan menunjukkan bahwa dari tahun 2007 sampai dengan 2012 Angka Kematian Neonatal (AKN) tidak menurun secara signifikan sejak 2007, sebesar 19 AKN per 1000 kelahiran hidup dari total 32 AKB per 1.000 kelahiran hidup. $^{7}$ Di Indonesia angka kematian bayi menurut
UNICEF sebanyak 30.000 dan setiap tahun ada 10 juta kematian balita. Secara empiris ASI eksklusif efektif dapat mencegah kematian bayi, tanpa harus menyediakan makanan atau minuman tambahan untuk bayi. Lancet (2010) menyatakan, menyusui eksklusif dapat mengurangi angka kematian bayi hingga $13 \%$ dan dapat mengurangi prevalensi balita pendek. Pemberian ASI 4 sampai 6 bulan secara eksklusif mengurangi morbiditas dan mortalitas pada balita. ${ }^{8}$

Ada bukti dari beberapa negara berkembang bahwa pemberian ASI eksklusif dalam jangka waktu berapapun dibandingkan dengan semua bentuk lain dari ASI lebih protektif terhadap beberapa infeksi dan penyakit selama masa bayi. Sebuah penelitian di Bangladesh menunjukkan menyusui sampai usia 6 bulan adalah faktor dominan dalam mengurangi morbiditas bayi. ${ }^{9}$ Menyusui eksklusif selama 6 bulan terbukti paling protektif, terutama terhadap infeksi saluran cerna yang merupakan penyebab utama kematian balita di seluruh dunia. ${ }^{10}$

Secara global, cakupan ASI Eksklusif mencapai $36 \%$ pada 2011.11 Menurut hasil survey kesehatan nasional tahun 2013, bahwa di Indonesia cakupan ASI eksklusif pada angka $38,0 \%$, yang jauh dari target WHA yaitu $50 \%$ pada tahun $2025 .{ }^{12}$ Sefene et al. (2013) melakukan penelitian di Kota Bahir Dar Ethiopia. Mereka menemukan prevalensi menyusui eksklusif $49,1 \% .{ }^{13}$ Varshney et al. (2012) menemukan hasil yang berbeda, dalam penelitiannya di daerah kumuh perkotaan di kota Anand, Gujarat. Dia menemukan prevalensi ASI eksklusif $22,7 \% .^{14}$

Pada tahun 2015 pemerintah melalui Kementerian Kesehatan menetapkan target ASI eksklusif sebesar $39 \%$, melalui Target Rencana Strategi Kementerian Kesehatan, dan hal ini telah tercapai. Capaian pemberian ASI ekkslusif menurut Riset Kesehatan Dasar (Riskesdas) tahun 2013, pada bayi usia 0-6 bulan di Propinsi Sulawesi Selatan yaitu 
$71,5 \%$, artinya jumlah bayi yang mendapatkan ASI tanpa makanan pendamping sampai usia kurang enam bulan Propinsi Sulawesi Selatan telah mencapai target, dan hampir mencapai level tertinggi target cakupan ASI eksklusif tahun 2019 yaitu sebesar $80 \%{ }^{5,16}$

Ada 28,01 juta orang atau $10,86 \%$ pada Maret 2016 penduduk miskin di Indonesia, dengan jumlah penduduk miskin di daerah perkotaan pada maret 2016 sebesar 10,34 juta orang atau $7,79 \% .{ }^{17}$ Upaya kesehatan bagi kelompok miskin kota yang sebagian besar tinggal di permukiman kumuh dapat dilihat dengan adanya publikasi WHO dan UN-Habitat tentang pembangunan kota seperti laporan pertemuan regional WHO 2011 dan publikasi WHO dan UN-Habitat pada tahun yang sama. ${ }^{18}$

Penelitian tentang cakupan dan determinan ASI eksklusif umumnya dilakukan pada penduduk yang bersifat umum atau kelompok umur tertentu. Meningkatnya urbanisasi pada perkotaan merupakan sebab tingginya populasi pada pemukiman kumuh dalam perkotaan di negara berkembang. ${ }^{14}$ Menurut Undang-Undang Nomor 01 tahun 2011 tentang pemukiman merujuk pada kualitas bangunan, tingkat kepadatan bangunan yang tinggi, dan permukiman yang tidak layak huni karena ketidakteraturan bangunan, serta tidak terpenuhinya syarat sarana dan prasarana merupakan kategori dalam pemukiman kumuh. Daerah perkotaan memiliki pertumbuhan yang cepat juga pada populasi kumuh. ${ }^{14}$

Isu penyakit infeksi seperti diare, infeksi pernapasan akut maupun penyakit tetanus masih menjadi penyebab nomon satu kematian bayi dan status ekonomi keluarga yang rendah ikut berperan dalam meningkatkan angka kematian bayi. Data menunjukkan bahwa angka kematian bayi pada golongan termiskin yaitu 61 per 1000 kelahiran hidup, jauh lebih tinggi dari golongan terkaya yaitu 17 per 1000 kelahiran hidup. ${ }^{8}$

Teori Green (1980) ada tiga faktor yang menentukan perilaku seseorang yaitu faktor pendukung (enabling factors), faktor predisposisi (predisposing factors), dan faktor pendorong/penguat (reinforcing factors). Faktor presdisposisi meliputi umur ibu, etnik, mode kelahiran, tempat melahirkan, tempat tinggal, paritas, konseling ANC tentang ASI eksklusif, pekerjaan, tingkat pendidikan ibu, tingkat pengetahuan ibu, sikap ibu terhadap ASI dan pendapatan. Faktor pendorong/penguat meliputi keterpaparan informasi dan faktor pendukung meliputi dukungan suami dan dukungan keluarga serta dukungan petugas kesehatan..$^{20}$

Penelitian ini bertujuan untuk menilai cakupan dan determinan pemberian ASI eksklusif di tujuh pemukiman kumuh dari sembilan lokasi kumuh yang ditetapkan oleh pemerintah daerah Makassar yaitu di Kecamatan Tallo.

\section{Bahan dan Metode}

Penelitian bersifat analitik observasional dengan pendekatan studi cross sectional. Lokasi penelitian di daerah kumuh perkotaan Kecamatan Tallo, Kota Makassar berdasarkan Surat Keputusan Walikota Makassar Nomor 050.05/1341/Kep/IX/2014 tentang Penetapan Lokasi Perumahan Kumuh, Kota Makassar dan dilakukan pada bulan April hingga Mei 2017.

Penelitian ini mempunyai populasi pada semua ibu yang memiliki bayi usia 7-12 bulan yang pada saat penelitian tinggal dan menetap di tujuh kelurahan berjumlah 283 orang. Dari populasi ibu yang memiliki bayi berusia 7-12 bulan, sebanyak 221 responden merupakan sampel penelitian. Teknik yang digunakan dalam penarikan sampel adalah total sampling yaitu semua ibu yang memiliki bayi 7-12 bulan yang tinggal dan menetap di permukiman kumuh di setiap RW. 
Data yang diambil adalah determinan pemberian ASI (umur ibu, etnik, jenis persalinan, paritas, tempat persalinan, pekerjaan ibu, pendapatan keluarga, pendidikan ibu, pengetahuan, keterpaparan informasi, dukungan suami, dukungan keluarga, dukungan petugas kesehatan, sikap dan kunjungan ANC responden terhadap pemberian ASI eksklusif). Data diperoleh melalui kuisioner yang diisi responden dengan metode wawancara, menggunakan formulir/kuisioner yang telah dibuat oleh peneliti. Data diproses dengan program SPSS 16.0. Pengolahan dan analisis data dilakukan sesuai tahapan penelitian dengan menggunakan uji Chi square dan phi pada batas signifikansi $a=0,05$. Untuk penyajian data dalam bentuk tabel disertai narasi berdasarkan variabel yang diteliti. ${ }^{20}$

\section{Hasil}

\section{Analisis Bivariat}

Pada Tabel 1 dapat diketahui distribusi determinan cakupan pemberian ASI eksklusif yang dipengaruhi oleh faktor predisposisi, faktor pendukukung, dan faktor pendorong di daerah kumuh Kecamatan Tallo Kota Makassar. Berdasarkan Tabel 1, ada 3 variabel yang mempengaruhi) cakupan pemberian ASI eksklusif yaitu variabel sikap, kunjungan perawatan antenatal, dan paparan informasi $(p<0,05)$. Sementara variabel umur, etnis, tingkat pendidikan, jenis pekerjaan, pendapatan keluarga, tempat lahir, jenis persalinan, pengetahuan ibu, dukungan keluarga, dan dukungan pemerintah tidak mempengaruhi cakupan pemberian ASI eksklusif.

\section{Analisis Multivariat}

Hasil analisis multivariat tentang determinan cakupan pemberian ASI eksklusif dapat diketahui pada Tabel 2. Hasil menunjukkan bahwa model variabel akhir yang mempengaruhi cakupan pemberian ASI eksklusif adalah kunjungan antenatal care dan sikap ibu.

\section{Pembahasan}

Hasil penelitian menemukan bahwa cakupan ASI eksklusif di pemukiman kumuh dalam perkotaan Kota Makassar yaitu sebesar 20,4\%. Jika dibandingkan dengan laporan cakupan ASI eksklusif di Dinas Kesehatan Kota Makassar tahun 2016 yaitu sebesar $72,43 \%$ dan capaian ASI eksklusif secara nasional yaitu sebesar $55,7 \%$ dan capaian ASI eksklusif menurut Riskesdas 2013 sebesar 38,0\%, serta target Renstra Kementerian Kesehatan sebesar 39\% di tahun 2015 dan target World Health Organization (WHO) tahun 2025 yaitu sebesar $50 \%$ maka cakupan ASI eksklusif dipemukiman kumuh dalam perkotaan Kecamatan Tallo Kota Makassar masih jauh lebih rendah dan belum mencapai target.

Sejalan dengan temuan ini, capaian cakupan ASI esklusif telah diamati oleh Varshney et al. (2012) di pemukiman kumuh dalam perkotaan di Kota Anand, India yaitu sebesar 22,7\%, dan penelitian Tiwari et al. (2009), di Kota Gwalior, India menemukan prevalensi bayi yang diberi ASI sampai usia 6 bulan sebesar $7,8 \% .^{14,21}$. Penelitian yang dilakukan oleh Tampah-Naah dan KumiKyereme (2013) di daerah bukan pemukiman kumuh Kota Ghana menemukan hasil yang berbeda yakni prevalensi pemberian ASI eksklusif sebesar $63 \%$. ${ }^{22}$

Pemukiman kumuh dan bukan pemukiman kumuh memiliki perbedaan capaian cakupan pemberian ASI eksklusif. Jika dibandingkan dengan pemukiman kumuh capaian ASI eksklusif di area bukan pemukiman kumuh jauh lebih tinggi dan mencapai target ASI eksklusif menurut WHO tahun 2025 dari pemukiman kumuh. 
Tabel 1. Hubungan faktor predisposisi, faktor pendukukung, dan faktor pendorong dengan cakupan ASI eksklusif di daerah kumuh Kecamatan Tallo Kota Makassar.

\begin{tabular}{|c|c|c|c|c|c|c|c|}
\hline \multirow{3}{*}{ Variabel } & \multicolumn{6}{|c|}{ ASI Eksklusif $(n=221)$} & \multirow{3}{*}{$P$ value } \\
\hline & \multicolumn{2}{|c|}{$\mathrm{Ya}$} & \multicolumn{2}{|c|}{ Tidak } & \multicolumn{2}{|c|}{ Total } & \\
\hline & $\mathrm{n}$ & $\%$ & $\mathrm{n}$ & $\%$ & $n$ & $\%$ & \\
\hline \multicolumn{8}{|l|}{ Usia Ibu (Tahun) } \\
\hline$\leq 20$ & 2 & 8,0 & 23 & 92,0 & 25 & 100 & 0,128 \\
\hline $21-25$ & 10 & 16,4 & 51 & 83,6 & 61 & 100 & \\
\hline $26-30$ & 19 & 30,6 & 43 & 69,4 & 62 & 100 & \\
\hline $31-35$ & 8 & 20,5 & 31 & 79,5 & 39 & 100 & \\
\hline$\geq 36$ & 6 & 17,6 & 28 & 82,4 & 34 & 100 & \\
\hline \multicolumn{8}{|l|}{ Suku } \\
\hline Suku Makassar & 37 & 20,6 & 143 & 79,4 & 180 & 100 & 0,881 \\
\hline Bukan Suku Makassar & 8 & 19,5 & 33 & 80,5 & 41 & 100 & \\
\hline \multicolumn{8}{|l|}{ Tingkat pendidikan } \\
\hline Tinggi & 17 & 21,8 & 61 & 78,2 & 78 & 100 & 0,696 \\
\hline Rendah & 28 & 19,6 & 115 & 80,4 & 143 & 100 & \\
\hline \multicolumn{8}{|l|}{ Pekerjaan ibu } \\
\hline Tidak bekerja & 42 & 21,4 & 154 & 78,6 & 196 & 100 & 0,270 \\
\hline Bekerja & 3 & 12,0 & 22 & 88,0 & 25 & 100 & \\
\hline \multicolumn{8}{|l|}{ Pendapatan keluarga } \\
\hline Tinggi & 12 & 20,0 & 48 & 80,0 & 60 & 100 & 0,935 \\
\hline Rendah & 33 & 20,5 & 128 & 79,5 & 161 & 100 & \\
\hline \multicolumn{8}{|l|}{ Tempat melahirkan } \\
\hline Pelayanan kesehatan & 44 & 21,5 & 161 & 78,5 & 205 & 100 & 0,146 \\
\hline Rumah & 1 & 6,2 & 15 & 93,8 & 16 & 100 & \\
\hline \multicolumn{8}{|l|}{ Jenis persalinan } \\
\hline Normal & 41 & 20,5 & 159 & 79,5 & 200 & 100 & 0,875 \\
\hline Sectio Caesarea & 4 & 19,0 & 17 & 81,0 & 21 & 100 & \\
\hline \multicolumn{8}{|l|}{ Paritas } \\
\hline Primipara & 8 & 13,3 & 52 & 86,7 & 60 & 100 & 0,113 \\
\hline Multipara & 37 & 23,0 & 124 & 77,0 & 161 & 100 & \\
\hline \multicolumn{8}{|l|}{ Pengetahuan ibu } \\
\hline Baik & 30 & 23,8 & 96 & 76,2 & 126 & 100 & 0,143 \\
\hline Kurang & 15 & 25,8 & 80 & 84,2 & 95 & 100 & \\
\hline \multicolumn{8}{|l|}{ Sikap } \\
\hline Positif & 34 & 29,1 & 83 & 70,9 & 117 & 100 & 0,001 \\
\hline Negatif & 11 & 10,6 & 93 & 89,4 & 104 & 100 & \\
\hline \multicolumn{8}{|l|}{ Keterpaparan informasi } \\
\hline Terpapar & 30 & 24,6 & 92 & 75,4 & 122 & 100 & 0,083 \\
\hline Tidak terpapar & 15 & 15.2 & 84 & 84,8 & 99 & 100 & \\
\hline \multicolumn{8}{|l|}{ Kunjungan Antenatal care } \\
\hline Komplit & 43 & 23,4 & 141 & 76,6 & 184 & 100 & 0,013 \\
\hline Tidak komplit & 2 & 5,4 & 35 & 94,6 & 176 & 100 & \\
\hline \multicolumn{8}{|l|}{ Dukungan suami } \\
\hline Baik & 34 & 23,1 & 113 & 76,9 & 147 & 100 & 0,150 \\
\hline Kurang & 11 & 14,9 & 63 & 85,1 & 74 & 100 & \\
\hline \multicolumn{8}{|l|}{ Dukungan keluarga } \\
\hline Baik & 34 & 23,3 & 112 & 76,7 & 146 & 100 & 0,132 \\
\hline Kurang & 11 & 14,7 & 64 & 85,3 & 75 & 100 & \\
\hline Dukungan petugas & & & & & & & \\
\hline Baik & 38 & 22,5 & 131 & 77,5 & 169 & 100 & 0,159 \\
\hline Kurang & 7 & 13,5 & 45 & 86,5 & 52 & 100 & \\
\hline
\end{tabular}


Tabel 2. Hasil analisis multivariat dengan menggunakan logistic regression metode Backward LR.

\begin{tabular}{lcccccc}
\hline \multicolumn{1}{c}{ Variable } & $\mathrm{B}$ & Wald & Sig. & OR & \multicolumn{2}{c}{$95 \% \mathrm{CL}$} \\
\cline { 6 - 7 } & & & & & $\mathrm{LL}$ & $\mathrm{UL}$ \\
\hline Keterpaparan informasi & -0.700 & 2.550 & 0.110 & 0.496 & 0.210 & 1.172 \\
Antenatal care & 1.634 & 4.657 & $0.031^{*}$ & 5.124 & 1.162 & 22.597 \\
Sikap & 1.241 & 10.392 & $0.001^{*}$ & 3.458 & 1.626 & 7.354 \\
Constant & -3.433 & 18.961 & & & & \\
\hline
\end{tabular}

${ }^{*}$ Significant $p<0.05$

Hasil penelitian menemukan bahwa rendahnya cakupan pemberian ASI eksklusif di pemukiman kumuh kecamatan Tallo Kota Makassar dipengaruhi oleh sikap ibu dan kunjungan ANC selama kehamilan. Hasil penelitian ini juga menemukan tidak ada hubungan antara pemberian ASI eksklusif dengan umur ibu, etnik, pekerjaan ibu, tingkat pendidikan ibu, tingkat pengetahuan, tempat persalinan, jenis persalinan, paritas, keterpaparan informasi, dukungan suami, dukungan keluarga dan dukungan petugas kesehatan.

Distribusi pernyataan sikap ibu terhadap ASI eksklusif umumnya atau sebagian besar ibu setuju dengan pernyataan bahwa susu formula adalah minuman terbaik bagi bayi baru lahir, memberikan susu formula lebih menyenangkan daripada menyusui, sebelum ASI keluar susu formula adalah makanan terbaik untuk diberikan kepada bayi baru lahir, sebelum mulai disusui, bayi baru lahir perlu diberi madu lebih dahulu, bila bayi masih rewel, maka selain ASI, bayi perlu diberi minuman atau makanan lain, bayi yang diberi pisang sebelum berusia 6 bulan akan lebih kuat daripada yang diberi ASI saja, bayi yang diberi susu formula sebelum berusia 6 bulan akan lebih cerdas daripada yang diberi ASI saja, campuran nasi dan pisang yang dihaluskan adalah makanan terbaik bagi bayi berusia kurang dari 6 bulan. Sebagian besar ibu yang masih beranggapan dan setuju dengan penyataan sikap bahwa bila suami dan ibu mertua mereka melarang untuk menyusui, maka mereka akan menurutinya.
Sejalan dengan penelitian Alamirew et al (2017) menggunakan desain cross sectional study di Pusat Kesehatan Dabat di daerah Barat Laut Ethiopia menemukan bahwa 92 (24\%) dari peserta penelitian dikategorikan memiliki sikap negatif terhadap pemberian ASI eksklusif dan sisanya 292 (76 $\%$ ) dikategorikan memiliki sikap positif.

Analisis bivariat menemukan bahwa ada hubungan sikap ibu dengan pemberian ASI eksklusif (Tabel 1). Ibu yang memiliki sikap positif terhadap ASI eksklusif akan mungkin memberikan ASI eksklusif. Sejalan dengan temuan ini, hubungan sikap ibu dengan pemberian ASI eksklusif diamati oleh beberapa penelitian lain di antaranya studi cross sectional yang dilakukan oleh Mogre et al (2016) di Kabupaten Tuna, Ghana, menemukan bahwa pemberian ASI eksklusif berhubungan dengan sikap ibu. ${ }^{23}$

Keberhasilan pemberian ASI eksklusif dapat melalui upaya seperti mengurangi keterpaparan masyarakat umum terhadap iklan pengganti susu, ibu tidak diberikan sampel gratis, fasilitas kesehatan tidak boleh mendapatkan promosi produk dan pekerja kesehatan tidak boleh diberikan hadiah. ${ }^{24}$

Penelitian ini juga menemukan bahwa ada hubungan kunjungan antenatal care (ANC) dengan perilaku menyusui. Ibu dengan kunjungan ANC yang baik memiliki peluang untuk menyusui bayinya dibanding dengan ibu yang tidak melakukan kunjungan ANC dengan baik. Proporsi ibu dengan kunjungan ANC baik lebih banyak memberikan ASI eksklusif dibanding dengan kunjungan ANC kurang baik. Namun, dalam 
proporsi ibu dengan kunjungan ANC baik, ibu yang tidak menyusui selama 6 bulan lebih banyak dibanding dengan proporsi ibu yang menyusui bayi sampai usia 6 bulan. Hal tersebut merupakan masalah baru dan menjadi pertanyaan bahwa jumlah kunjungan ANC tidak menjamin keberhasilan dalam pemberian ASI eksklusif.

Sejalan dengan penemuan ini, penelitian Ghwass and Ahmed (2011), menemukan bahwa ada hubungan kunjungan ANC dengan perilaku menyusui ibu sampai usia 6 bulan, yaitu ibu akan memiliki kemungkinan menyusui bayinya secara eksklusif dibanding dengan mereka yang tidak menerima konseling. ${ }^{25}$

Harapannya pelayanan ANC dapat mendorong ibu hamil untuk memberikan ASI eksklusif pada bayinya. Pelayanan ANC juga dapat merubah sikap ibu terhadap ASI eksklusif.24 Kunjungan ANC sangat bermanfaat bagi ibu hamil, salah satu tujuan dari pelayanan ANC adalah masa nifas yang dipersiapkan dengan baik, secara fisik dan psikologi dapat mendorong ibu untuk memberikan ASI secara eksklusif. Komponen informasi yang harus didapatkan tentang ASI eksklusif selama ibu melakukan kunjungan antenatal yaitu ibu harus menerima konseling atau penjelasan dari tenaga kesehatan tentang inisiasi menyusu dini (IMD), dan pemberian ASI eksklusif. Selain itu, ibu juga memperoleh konseling tentang perawatan kehamilan, perawatan bayi baru lahir, nifas, kelainan bawaan, persalinan, imunisasi pada bayi, dan keluarga berencana.

Komponen lain yang harus diterima ibu selama hamil sampai ibu melahirkan adalah pada pasca persalinan ibu harus menerima pelayanan kesehatan ibu nifas, salah satunya adalah konseling dari petugas kesehatan tentang teknik menyusui yang benar dan sampai usia 6 bulan bayi hanya diberi ASI saja, tidak membuang ASI yang pertama keluar (kolostrum) dan langsung memberikan ke bayi, cara memerah dan menyimpan ASI.
Hasil penelitian menemukan bahwa pemberian ASI eksklusif tidak berhubungan dengan umur ibu. Tidak ada perbedaan yang signifikan persentase pada setiap kelompok umur ibu yang menyusui sampai 6 bulan Meskipun kelompok umur ibu 26-30 tahun merupakan kelompok umur dengan pemberian ASI eksklusif tertinggi. Penelitian Jara-Palacios et al. (2015) di Equador menemukan hal yang sama yaitu pada subjek penelitian tersebut fokus pada ibu remaja usia 14-19 tahun. Penelitian oleh Fombong et al. (2016) di Cameroon menemukan bahwa pemberian ASI eksklusif tidak berhubungan dengan umur ibu. ${ }^{10,26}$

Menurut Kementerian Kesehatan RI (2014), salah satu faktor yang penting yang mendukung proses kehamilan adalah umur ibu waktu hamil. ${ }^{27}$ Penelitian yang dilakukan di China pada tahun 2004-2005 menunjukkan bahwa pemberian ASI eksklusif sangat baik diberikan oleh ibu jika berusia lebih dari 24 tahun. ${ }^{28}$

Perilaku menyusui sampai 6 bulan berhubungan dengan suku atau enik. Meskipun suku atau etnik yang mendominasi dalam lokasi penelitian ini adalah suku Makassar tetapi pengaruh budaya sudah tidak lagi menjadi penyebab gagalnya program pemerintah terkait ibu menyusui sampai 6 bulan. Hal ini dapat dilihat dari tingginya persentase ibu yang sudah terpapar informasi tentang perilaku menyusui sampai 6 bulan.

Adapun variabel tingkat pendidikan tidak berhubungan dalam penelitian ini. Tingkat pendidikan mempengaruhi pengetahuan seseorang. Hal tersebut dapat dilihat dari ibu dengan pendidikan Diploma/S1 masih mendominasi pemberian ASI eksklusif. Meskipun proporsi ibu dengan pendidikan tinggi tersebut lebih tinggi tidak memberikan ASI eksklusif dibanding dengan yang memberikan ASI eksklusif. Tingkat pendidikan telah diamati oleh beberapa penelitian, di antaranya penelitian yang 
dilakukan oleh Jara-Palacios et al. (2015) yang membagi tingkat pendidikan tinggi dan rendah diketahui tidak berhubungan dengan perilaku menyusui sampai 6 bulan. ${ }^{26}$

Pemberian ASI eksklusif tidak berhubungan dengan jenis pekerjaan ibu. Meskipun persentase ibu yang tidak bekerja (IRT) lebih banyak memberikan ASI eksklusif dibanding dengan ibu rumah tangga dan memiliki usaha tetapi hal tersebut tidak menjadi faktor keberhasilan pemberian ASI eksklusif. Ibu rumah tangga memiliki banyak waktu atau kesempatan untuk memberikan ASI eksklusif tetapi banyak faktor lain yang dapat mempengaruhi hal tersebut. Pekerjaan ibu telah diamati oleh Sefene et al. (2013) dan Thakur et al. (2016) menemukan bahwa tidak ada hubungan pekerjan ibu dengan pemberian ASI eksklusif. ${ }^{13,29}$. Berbeda dengan penelitian yang dilakukan oleh Warsini (2015) menemukan bahwa pekerjaan ibu memiliki kaitan dengan pemberian ASI eksklusif yang menjadi salah satu penyebab ketidak berhasilan ASI eksklusif adalah ibu bekerja. ${ }^{30}$

Penelitian ini menemukan tidak ada hubungan pendapatan keluarga dengan pemberian ASI eksklusif. Tidak terdapat perbedaan yang cukup jauh persentase pendapatan keluarga, baik keluarga dengan pendapatan tinggi maupun keluarga dengan pendapatan rendah terhadap pemberian ASI eksklusif. Jadi, keluarga dengan pendapatan tinggi maupun keluarga dengan pendapatan rendah tidak menjamin keberhasilan pemberian ASI eksklusif. Penelitian Sefene et al. (2013) menemukan bahwa pendapatan tidak terkait dengan pemberian ASI eksklusif. ${ }^{13}$ Berbeda dengan penelitian yang dilakukan oleh Ayawine dan Ayuurebobi (2015) serta Thakur et al. (2016) menemukan bahwa ada relasi antara pendapatan dengan pemberian ASI eksklusif. ${ }^{31,29}$

Tingkat sosial ekonomi merupakan faktor dominan yang mempengaruhi pola pemberian ASI, dengan peluang ibu memberikan ASI sebesar 4,6 kali lebih besar pada ibu sosial ekonomi rendah dibanding dengan ibu sosial ekonomi tinggi. ${ }^{32}$ Faktor sosial ekonomi merupakan salah satu faktor penentu mortalitas pada bayi dan anak, tetapi hal tersebut bukan penyebab langsung tetapi ada suatu patomekanisme tertentu yang kemudian melibatkan pendapatan rendah sebagai faktor risiko morbiditas pada bayi dan jika tidak dapat disembuhkan maka akan berujung pada kematian. ${ }^{8}$

Tempat persalinan juga tidak berhubungan dengan pemberian ASI eksklusif. Meskipun proporsi ibu yang melahirkan di fasilitas kesehatan jauh lebih tinggi memberikan ASI eksklusif dibandingkan dengan proporsi ibu yang melahirkan di rumah, tetapi hal tersebut tidak mempengaruhi keberhasilan ASI eksklusif. Seharusnya, ibu yang melahirkan di fasilitas kesehatan memiliki kesempatan untuk memberikan ASI eksklusif tetapi ketidak bermaknaan tempat melahirkan dengan pemberian ASI eksklusif dapat disebabkan oleh faktor lain.

Selain itu, diketahui jenis persalinan tidak berhubungan dengan pemberian ASI eksklusif. Hal tersebut dapat dipengaruhi oleh proporsi ibu yang memberikan ASI eksklusif pada ibu yang melahirkan secara normal maupun dengan operasi sesar hampir tidak ada perbedaan. Hal tersebut menjadi salah satu faktor ketidak bermaknaan jenis persalinan dengan keberhasilan pemberian ASI eksklusif. Kaitan jenis persalinan dengan pemberian ASI eksklusif telah diamati oleh Sapna et al. (2009) di pemukiman dalam perkotaan India, dan Thakur et al. (2016), menemukan bahwa tidak ada hubungan jenis persalinan dengan pemberian ASI eksklusif. 29,33

Pemberian ASI eksklusif tidak berhubungan dengan paritas, meskipun dalam penelitian ditemukan banyak ibu multipara memberikan ASI dibandingkan primipara dan grandemultipara tetapi hal 
tersebut tidak mempengaruhi keberhasilan pemberian ASI eksklusif. Penelitian oleh Kurniawan (2013) di Rumah Sakit Muhammadiyah Lamongan dengan populasi ibu dari anak berusia 5-24 bulan yang menjadi pasien rawat jalan atau rawat inap di RS tersebut. ${ }^{34}$ Dave et al. (2014) di pemukiman kumuh kota Anand India, menemukan bahwa paritas tidak berhubungan dengan pemberian ASI eksklusif. ${ }^{35}$

Ada banyak faktor yang mempengaruhi perilaku ibu untuk menyusui yang berhubungan dengan paritas seperti perilaku ibu memberikan ASI pada kelahiran sebelumnya, pengetahuan ibu tentang manfaat ASI, adanya suatu kebiasaan dalam keluarga untuk menyusui. Oleh karena itu paritas sangat berimplikasi pada perilaku ibu mesikpun dalam penelitian ini tidak berhubungan.

Penelitian ini menemukan tidak ada hubungan tingkat pengetahuan ibu, keterpaparan informasi, dukungan petugas kesehatan, dukungan suami, dukungan keluarga dengan perilaku menyusui sampai bayi usia 6 bulan.

\section{Kesimpulan}

Kesimpulan dari penelitian ini adalah cakupan pemberian ASI eksklusif pada bayi sampai usia 6 bulan di Kecamatan Tallo, Kota Makassar sebesar 20,4\%. Sikap ibu menunjukkan hubungan bermakna $(\mathrm{OR}=$ $3.458 ; 95 \% \mathrm{Cl}=1.626-7.354)(\mathrm{P}=0,001)$ dan kunjungan ANC $(\mathrm{OR}=5,124 ; 95 \% \mathrm{Cl}=1,162$ 22.597) $(P=0,031)$ dengan pemberian ASI eksklusif. Akan tetapi, umur ibu, etnik, jenis persalinan, paritas, tempat persalinan, pekerjaan ibu, pendapatan keluarga, pendidikan ibu, pengetahuan, keterpaparan informasi, dukungan suami, dukungan keluarga, dukungan petugas kesehatan tidak berhubungan dengan pemberian ASI eksklusif.

\section{Saran}

Perlu perhatian khusus dalam upaya meningkatkan cakupan pemberian ASI eksklusif yang berbeda dari populasi lain. Perlunya upaya untuk meningkatkan sikap ibu tentang komunikasi, informasi dan pendidikan tentang kolostrum, inisiasi menyusu dini (IMD) dan pemberian ASI sebelum masa menyusui. Peningkatan pemberian ASI eksklusif dengan konseling tentang pemberian ASI eksklusif mulai dari persalinan, selama persalinan dan postpartum dengan mempertimbangkan persepsi ibu terutama yang bersikap negatif terhadap pemberian ASI eksklusif di permukiman kumuh Kecamatan Tallo Kota Makassar.

\section{Daftar Pustaka}

1. WHO. Global Strategy for Infant and Young Child Feeding. Global Strategy for Infant and Young Child Feeding. Genewa: $\quad$ WHO. 2003. http://apps.who.int/iris/bitstream/handle/

2. Gupta, A., Dadhich, J. P. \& Faridi, M. M. Breastfeeding And Complementary Feeding As A Public Health Intervention For Child Survival In India. Indian J Pediatr, 77, 413-8. Epub 2010 Mar 19. Available From: Https://Www.Ncbi.NIm.Nih.Gov/Pubmed/

3. Keino, S., Plasqui, G., Ettyang, G. \& Van Den Borne, B. Determinants Of Stunting And Overweight Among Young Children And Adolescents In Sub-Saharan Africa. Food Nutr Bull, 35, 167-78. Published: 2014 Jun; Available From: Https://Www.Ncbi.Nlm.Nih.Gov/Pubmed/

4. Heymann, J., Raub, A. \& Earle, A. Breastfeeding Policy: A Globally Comparative Analysis. Bulletin Of The World Health Organization, 91, 398406. Available From: 
Http://Www.Who.Int/Bulletin/Volumes/

5. Unicef \& Who 2006. Pneumonia The Forgotten Killer Of Children. New York, Geneva: The United Nations Children's Fund (Unicef). World Health Organization (Who). Available From: Http://Www.Who.Int/Maternal_Child_Ad olescent/Documents/

6. Edmond, K. M., Zandoh, C., Quigley, M. A., Amenga-Etego, $S$., Owusu-Agyei, S. \& Kirkwood, B. R. 2006. Delayed Breastfeeding Initiation Increases Risk Of Neonatal Mortality. Pediatrics, 117, E380-6. Published : 2006 Mar. Available From: Https://Www.Ncbi.Nlm.Nih.Gov/Pubmed/

7. Kemenkes. Survei Demografi Dan Kesehatan Indonesia 2012. Jakarta. Kemenkes Ri. 2013b. Http://Www.Depkes.Go.Id/Resources/Do wnload/Pusdatin/

8. Amiruddin, R. \& Hasmi 2014 Determinan Kesehatan Ibu Dan Anak, Jakarta, Cv. Trans Info Media.

9. Mihrshahi, S., Oddy, W. H., Peat, J. K. \& Kabir, I. Association Between Infant Feeding Patterns And Diarrhoeal And Respiratory IIIness: A Cohort Study In Chittagong, Bangladesh. Int Breastfeed J, 3, 28. 2008 Nov 24;3:28. Doi: 10.1186/17464358-3-28. Available From: Https://Www.Ncbi.Nlm.Nih.Gov/Pubmed/

10. Fombong, F. E., Olang, B., Antai, D., Osuorah, C. D., Poortvliet, E. \& Yngve, A. Maternal SocioDemographic Determinants Of Exclusive Breastfeeding Practice In Cameroon. American Journal Of Food And Nutrition, 4, 83-92. Available From: Http://Pubs.Sciepub.Com/Aifn/4/4/1/

11. Kramer, M. \& Kakuma, R. 2002. Optimal Duration Of Exclusive Breastfeeding (Review). Cochrane Database of Systematic Reviews, 1, 11-12.
12. Who \& Unicef. Global Nutrition Targets 2025: Breastfeeding Policy Brief. 2014. Http://Www.Who.Int/Nutrition/Publication sl

13. Sefene, A., Birhanu, D., Awoke, W. \& Taye, T. Determinants Of Exclusive Breastfeeding Practice Among Mothers Of Children Age Less Than 6 Month In Bahir Dar City Administration, Northwest Ethiopia; A Community Based Cross-Sectional Survey. Sci J Clin Med, 2, 153-9. Publication: October 20, 2013. Available From: Http://Article.Sciencepublishinggroup.Co $\mathrm{m} / \mathrm{Pdf} /$

14. Varshney, A., Kumar, D., Patel, M. \& Singh, U. Determinants Of Breastfeeding Practices In Urban Slums Of A Taluka Headquarter Of District Anand, Gujarat. Natl J Community Med, 3, 534-7. Publication: 01-09-12. Available From: Http://Njcmindia.Org/Uploads/

15. Kemenkes. Rencana Strategis Kementerian Kesehatan Tahun 20152019.

Http://Www.Depkes.Go.Id/Resources/Do wnload/Info-Publik/

16. Bapennas, Evaluasi Pelaksanaan Pembangunan Nasional Tahun 20102014 (Capaian Prioritas Nasional Kinerja Kementerian Dan Daerah). Jakarta. 2014. Https://Www.Bappenas.Go.Id/

17. Bps, 2016b. Profil Kemiskinan Di Indonesia September 2016. Https://Www.Bps.Go.Id/Pressrelease

18. World Health Organization And UnHabitat. Hidden Cities: Unmasking And Overcoming Health Inequities In Urban Settings. Http:// Www.Who.Int/Kobe_Centre/Publications /Hidden_Cities2010/En/

19. Pmk. Peraturan Menteri Kesehatan Republik Indonesia Nomor 39 Tahun 2016 Tentang Pedoman Penyelenggaraan Program Indonesia 
Sehat

Dengan Pendekatan Keluarga. Jakarta.

Available

From:

Http://Www.Depkes.Go.Id/Resources/Do

wnload/Lain/Pmk_No.39_Ttg_Pis_Pk

20. Notoatmodjo. Promosi Kesehatan Teori

Dan Aplikasi, Jakarta, Rineka Cipta. 2010.

21. Tiwari, R., Mahajan, P. \& Lahariya, C. The Determinants Of Exclusive Breast Feeding In Urban Slums: A Community Based Study. Journal of Tropical Pediatrics, 55, 49-54. Epub 2008 May 22. Available From: Https://Www.Ncbi.Nlm.Nih.Gov/Pubmed/

22. Tampah-Naah, A. M. \& Kumi-Kyereme, A. Determinants of Exclusive Breastfeeding Among Mothers In Ghana: A Cross-Sectional Study. International Breastfeeding Journal, 8, 13. Published: 14 October 2013. Available From: Https://Internationalbreastfeedingjournal. Biomedcentral.Com/Articles/

23. Mogre, V., Dery, M. \& Gaa, P. K Knowledge, Attitudes And Determinants Of Exclusive Breastfeeding Practice Among Ghanaian Rural Lactating Mothers. Int Breastfeed J, 11, 12. Published: 17 May $2016 . \quad$ Available From:

Https://Internationalbreastfeedingjournal. Biomedcentral.Com/Articles/

24. Yngve, A. \& Sjöström, M. Breastfeeding Determinants And A Suggested Framework For Action In Europe. Public Health Nutrition, 4, 729-739. Published : 2001 Apr;4. Available From: Https://Www.Ncbi.Nlm.Nih.Gov/Pubmed/

25. Ghwass, M. M. A. \& Ahmed, D. Prevalence And Predictors Of 6-Month Exclusive Breastfeeding In A Rural Area In Egypt. Breastfeeding Medicine, 6, 191-196. Published: 2011 Aug;6. Available From: Https://Www.Ncbi.NIm.Nih.Gov/Pubmed/
26. Jara-Palacios, M. Á., Cornejo, A. C., Peláez, G. A., Verdesoto, J. \& Galvis, A. A. Prevalence And Determinants of Exclusive Breastfeeding Among Adolescent Mothers From Quito, Ecuador: A Crosssectional Study. International Breastfeeding Journal, 10, 33. Published April 9, 2018. Available From: Http://Journals.Sagepub.Com/Doi/Abs/

27. Kemenkes. Info Datin Situasi Kesehatan Reproduksi Remaja. Kementrian Kesehatan Ri: Jakarta Selatan. 2014. Available From: Http://Www.Depkes.Go.Id/Resources/Do wnload/Pusdatin/Infodatin/

28. Qiu, L., Zhao, Y., Binns, C. W., Lee, A. H. \& Xie, X. Initiation Of Breastfeeding And Prevalence Of Exclusive Breastfeeding At Hospital Discharge In Urban, Suburban And Rural Areas of Zhejiang China. International Breastfeeding Journal, 4, 1. Published Online 2009 Jan 28. Available From: Https://Www.Ncbi.Nlm.Nih.Gov/Pmc/Arti cles/

29.Thakur, N., Gupta, A., Chhabra, P. \& Dadhich, J. P. A Study Of Determinants Of Infant Feeding Practices In A Resettlement Colony Of Delhi, India. International Journal of Community Medicine And Public Health, 2016 Dec;3(12):3357-3363. Available From: Www.ljcmph.Com/Index.Php/licmph/Arti cle/

30. Warsini. Hubungan Antara Persalinan, Tingkat Pendidikan, Tingkat Pendapatan Dan Status Bekerja lbu Dengan Keberhasilan Asi Eksklusif 6 Bulan. Sebelas Maret. 2015. Available From: Https://Digilib.Uns.Ac.Id/Dokumen/

31. Ayawine, A. \& Ayuurebobi, K. Determinants of Exclusive Breastfeeding: A Study Of Two SubDistricts In The Atwima Nwabiagya District 
Of Ghana. The Pan African Medical Journal, 22. Published Online 2015 Nov 17. Available From: Https://Www.Ncbi.NIm.Nih.Gov/Pmc/Arti cles/

32. Ida. Faktor-Faktor Yang Berhubungan Dengan Pemberian Asi Eksklusif 6 Bulan Di Wilayah Kerja Puskesmas Kemiri Muka Kota Depok Tahun 2011. 2012. Universitas Indonesia.Thesis. Available From: Http://Lib.Ui.Ac.Id/File?

33. Sapna, S., Ameya, A., Rooma, S., Aarti, P., Rashid, A. \& Narayan, K. Prevalence Of Exclusive Breastfeeding And Its Correlates In An Urban Slum In Western India. International Ejournal Of Science Medicine \& Education, Published Online 2013 Oct 23. Available From:
Https://Www.Ncbi.NIm.Nih.Gov/Pmc/Arti cles/

34. Kurniawan, B. Determinan Keberhasilan Pemberian Air Susu lbu Eksklusif. 2013. Jurnal Kedokteran Brawijaya, 27, 236-240. Available From: Http://Jkb.Ub.Ac.Id/Index.Php/Jkb/

35. Dave, V. R., Shah, V. R., Sonaliya, K. \& Solanki, A. K. Assessment Of Breastfeeding Practices: Findings From Urban Slum Area At Ahmedabad City, India. Gcsmc Journal Of Medical Sciences, 1, 9-15. Available From: Https://Www.Ncbi.Nlm.Nih.Gov/Pmc/Arti $\underline{\text { cles/ }}$ 